3. Soros P, Whitehead S, Spence JD, Hachinski V. Antihypertensive treatment can prevent stroke and cognitive decline. Nat Rev Neurol 2013;9:174-178.

\section{ANTITHROMBOTIC DRUGS AND RISK OF HEMORRHAGIC STROKE IN THE GENERAL POPULATION}

Simone Vidale, Como, Italy: Garcia-Rodriguez et al. ${ }^{1}$ examined the risk of hemorrhagic stroke in patients treated with antithrombotics. While warfarin increased the risk of both intracerebral hemorrhage $(\mathrm{ICH})$ and subarachnoid hemorrhage $(\mathrm{SAH})$, aspirin did not influence the risk of ICH and surprisingly decreased the frequency of SAH.

The authors did not distinguish between SAH where an aneurysm was identified vs SAH where no aneurysm was found. This would have been useful as previous studies have indicated that aspirin may protect against aneurysm rupture. ${ }^{2}$ In addition, the highest risk of $\mathrm{ICH}$ was found in the short-duration group of warfarin users. This may be due to maintaining a balanced control of anticoagulation at the beginning of the treatment. Similar risk has been observed in recent trials comparing rivaroxaban to warfarin. ${ }^{3}$ It would be interesting to evaluate some characteristics of the patients' international normalized ratio trend-age or concomitant hypertension-to verify other predisposing factors vs the HAS-BLED score.
The addition of an antiplatelet to warfarin does not increase the risk of ICH vs users taking only warfarin. Adding antiplatelets in patients taking warfarin and affected by acute ischemic events might be beneficial by reducing the risk of further thrombotic episodes without the increase in cerebral bleeding risk. In this cohort study, it could be interesting also to identify characteristics (i.e., demographics and vascular risk factors) of patients with ICH treated with antiplatelets and warfarin to detect a risk profile for cerebral hemorrhage.

Finally, in this population-based study, the dual antiplatelet therapy (clopidogrel and aspirin) did not increase the risk of ICH significantly, which conflicts with previous clinical studies. ${ }^{4}$ This finding demonstrates that the "real world" might be better in results than the "trial world."

(C) 2014 American Academy of Neurology

1. Garcia-Rodriguez LA, Gaist D, Morton J, et al. Antithrombotic drugs and risk of hemorrhagic stroke in the general population. Neurology 2013;81:566-574.

2. Hasan DM, Mahaney KB, Brown RD Jr, et al. Aspirin as a promising agent for decreasing incidence of cerebral aneurysm rupture. Stroke 2011;42:3156-3162.

3. Mahaffey KW, Wojdyla D, Hankey G, et al. Clinical outcomes with rivaroxaban in patients transitioned from vitamin $\mathrm{K}$ antagonist therapy: a subgroup analysis of a randomized trial. Ann Intern Med 2013;158:861-868.

4. Field TS, Nakajima M, Benavente OR. Combination aspirin and clopidogrel for secondary prevention of ischemic stroke. Curr Treat Opt Cardiovasc Med 2013;15:348-359.

\title{
CORRECTION
}

Naive CD4 T-cell activation identifies MS patients having rapid transition to progressive MS

When the original version of the article "Naive CD4 T-cell activation identifies MS patients having rapid transition to progressive MS" by E. Zastepa et al. (Neurology 2014;82:681-690) was published online ahead of print on January 22, 2014, there was an error in table 1 . In the column "SP-1 ( $=6)$," line 2, "Age at MS onset, y (SD)" should have read "30.5 (10.2)." The errors were corrected in version 2, which was posted online ahead of print on February 14, 2014. The authors regret the errors. 


\section{Neurology}

\section{Naive CD4 T-cell activation identifies MS patients having rapid transition to progressive MS \\ Neurology 2014;82;1193 \\ DOI 10.1212/WNL.0000000000000329}

\section{This information is current as of March 31, 2014}

$\begin{array}{ll}\begin{array}{l}\text { Updated Information \& } \\ \text { Services }\end{array} & \begin{array}{l}\text { including high resolution figures, can be found at: } \\ \text { http://n.neurology.org/content/82/13/1193.2.full }\end{array} \\ \text { Permissions \& Licensing } & \begin{array}{l}\text { Information about reproducing this article in parts (figures,tables) or in } \\ \text { its entirety can be found online at: } \\ \text { http://www.neurology.org/about/about_the_journal\#permissions }\end{array} \\ & \begin{array}{l}\text { Information about ordering reprints can be found online: } \\ \text { http://n.neurology.org/subscribers/advertise }\end{array}\end{array}$

Neurology ${ }^{\circledR}$ is the official journal of the American Academy of Neurology. Published continuously since 1951, it is now a weekly with 48 issues per year. Copyright (O 2014 American Academy of Neurology. All rights reserved. Print ISSN: 0028-3878. Online ISSN: 1526-632X.

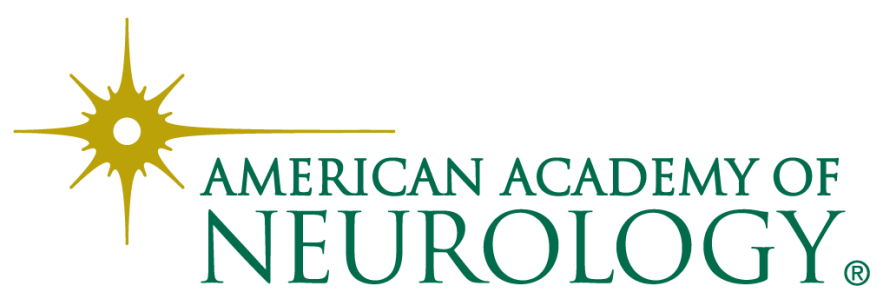

